\title{
Conceptualization of Man's Behavioral and Physical Characteristics as Animal Metaphors in the Spoken Discourse of Khezel People*
}

\author{
Mohammad Aliakbari and Elham Faraji (Ilam, Iran)
}

\begin{abstract}
Cognitive theory of metaphor has changed our understanding of metaphor as a figurative device to a matter of thought. It holds that metaphors are cognitively as well as culturally motivated.Despite having similar images in some languages, the culture-specific aspect of animal metaphors inspired the researchers to explore this area of metaphoric system in a local Kurdish variety to investigate how animal metaphors are reflected in spoken discourse. To achieve this objective, the authors collected and analyzed animal expressions adopted for praise and degradation of physical and behavioral characteristics in Khezeli dialect in Ilam, Iran. To create a representative corpus, the authors scrutinized spoken language and oral poetry of the dialect. The collected data indicate that more wild than domestic and more degrading than praising animal expressions are used for man's physical and behavioral characteristics. It is also confirmed that aspects of appearance, size, physical characteristics as well as body parts of animals are transferred to humans. Further, users' attitudes toward animals reflected themselves in their metaphors. Users were also found to have three categories of positive, positive/negative, and negative connotations for animal names. Despite the existence of similarities in the underlying patterns of metaphoric use in different languages, the research came to the conclusion that the types of animals used, their connotations and interpretations may be worlds apart and taking the meaning of one for another may lead to misunderstanding.
\end{abstract}

\section{$1 \quad$ Introduction}

The study of metaphor has received a great deal of attention since the beginning of the $20^{\text {th }}$ century and with the development of cognitive science, artificial intelligence, and brain and mind studies. It has recently penetrated into different fields of study including linguistics, anthropology, philosophy, psychology, education, sciences, literary criticism, rhetoric (Ying 2007) as well as literary theory, semiotics, and stylistics (Taverniers 2004). The view of metaphor since Lakoff and Johnson (1980) has changed from that of merely a figurative device

\footnotetext{
*We would like to express our deep appreciation and thanks to those people from Khezel tribe who honorably helped us with this study. We are especially indebted to Mrs. Kharaman Nyazyan, Mr. Ghyasi Faraji, Mrs. Leila Omidi and Mr. Taleb Omidi for their gentle and helpful guidance all through the project.The authors would also like to express their gratitude to the journal's editors and anonymous referees, whose comments, suggestions, and recommendations elevated the quality of the study and made its publication possible.
} 
to a matter of thought. Moreover, the essence of metaphor, as Lakoff and Johnson (1980) maintain, is understanding and experiencing one kind of thing in terms of another.

Basic ideas of Lakoff and Johnson have been termed cognitive theory of metaphor.Lakoff and Turner (1989: 65) believe that "we conventionally understand these concepts not by virtue of metaphoric mappings between them and different conceptual domains but rather by virtue of their grounding in what we take to be our forms of life, our habitual and routine bodily and social experience". Such a belief suggests that the human conceptual system is structured in a metaphorical way.

Lakoff and Johnson (1980: 41) confirm that "metaphors are not random but instead coherent systems, in terms of which we conceptualize our experience". Barcelona (2000) takes it as a cognitive mechanism by which one experiential domain is partially "mapped" or projected onto a different experiential domain. That is, the second domain is partially understood in terms of the first one. Stated differently, the target domain is source domain and the basic correspondences between these two domains accounts for this sort of relationship.

As Song (2009) maintains, the colorful animal kingdom is closely linked with our life and the relationship between humans and animals makes people familiar with the habits of animals. Consequently, people associate some of the animal characters with someone's characters in human life. That is why animal metaphors are present in languages and, as several authors have pointed out, these metaphors are cognitively as well as culturally motivated (e.g. Martsa 2000; Li 2001; Kövecses 2003; Talebinejhad/Dastjerdi 2005).According to Kövecses (2002: 124), "much of human behavior seems to be metaphorically understood in terms of animal behavior. That is, animals as metaphors for our fears, aspirations and desires, and our physical, emotional and spiritual connections with the animal world". For the same reason, Song (2009) suggests that one of the richest areas for the study of conceptual metaphor in different languages is the animal field. In addition, as Leung (2008: 21-23) confirms, "conceptual metaphors are frequently articulated in language, which is a key component of culture. In turn, language serves as a principal indicator of conceptual metaphors". Therefore, it is rightto say that in studying the conceptual metaphors of a language, researchers may gain insight into the culture of that particular language. Such an issue inspired the researchers to explore animal metaphor as an index of the metaphoric system of the language. More specifically, this study tries to investigate animal metaphors in one dialect of the Kurdish language spoken by people in the province of Ilam, west of Iran with the aim of gaining insight into the language-culturerelationship.

\section{Background}

As a pioneering study, Brinkmann (1878) investigated animal expressions (AE) in English, German, Italian, Spanish, French and Portuguese with the focus on domestic animal names. Three decades later, Riegler (1907) completed Brinkmann's collection with wild animal names. They both studied the origins of the AEs and Riegler also reported the etymology of the animal names. Fraser (1981) examined insulting terms using animal names in eleven languages. The aim was to inspect if the informants had equivalent usage in their native languages as the English stupid-donkey, coward-chicken, sneaky-snake, mean-dog, nasty-rat and dirty-pig. Taggart (1982) in a study on animal metaphors described how Spanish and Mexican Indian 
narrators developed different animal metaphors in cognate stories to fit their contrasting views of the universe.

Thornton (1989) conducted a study in which the semantics of animal terms used for good and evil people was scrutinized. The results of the study showed that among so many animal names which were used in different metaphorical expressions and which referred to people, mammals were the most used animal terms. Thornton, thus, argued that HUMANS were most often represented by the category mammals mainly because of their similarity, familiarity, and closeness to mankind.On the contrary, the smallest number of animal terms used with reference to HUMANS was derived from the class which was probably the least similar, familiar, and close to the human species, that is to say CRUSTACEANS.

O'Donnell (1990) placed his focus on the description of common and productive figurative meanings assigned to animal names and animal metaphors in different languages. Howard and Rensel (1991) have examined the role of animals in Rotuman sayings and the way in which they reflected Rotuman cultural values and attitudes. In her article on animal terms, Nesi (1995) discussed the figurative meanings of the names ofdifferent animals in different cultures, and highlighted someof the problems language learners and translators faced whendealing with single-word conventional metaphor. Informants fromthirty eight geographical regions responded to a questionnaireinviting them to comment on the figurative use made of animalnames in their cultures. Many common terms such as cat,cow and mouse were found to havea wide range of figurative meanings, and discussions with informantsrevealed that even advanced learners tended to think in termsof the connotations of their first culture when they encountered or used these words in a figurative sense in English.

In their study of metaphor in English and Chinese, Ahrens and Say (1999) concluded that the HUMANS ARE (UNDERSTOOD AS) ANIMAL metaphor existed in English and Chinese. The image-schemas mapped in both languages were appearances and behaviors. Yet, in Chinese, the appearance mapping was restricted to body parts of animals. Hsieh (2001) in her extensive study of animal metaphor in German and Chinese argued that the mechanism of zoosemy clearly reflected the ways of thinking and the cultural peculiarities of particular societies. These metaphors emerged from literary works, mass media or contact with other languages.The author believed that the majority of these metaphors were constructed with regard to appearances, conduct, and character of the respective animals. She, further, explored domestic, wild and mythical creatures and maintained that the related metaphors were positive, negative, or neutral. In another study, Hsieh (2004) presented the results of the cross-cultural study of Mandarian Chinese corpus and a German corpus of fixed animal expressions. The Chinese corpus contained 2980 and the German corpus 2630 written and spoken animal expressions. As she concluded, animal expressions were used by people to express their values and to criticize their conduct.

Fernández Fontecha and Jiménez Catalán (2003) concentrated on the word pairs fox/vixen and bull/cow and their Spanish counterparts zorro/zorra and toro/vaca with the data from dictionaries to investigate the semantic derogation of the related animal metaphors and concepts. They found that, with mapping from source to target domain, the main metaphorical meanings of the female terms connoted worse qualities than those connoted by the metaphors of the male terms. 
In a cross-cultural comparison of animal metaphors in English and Persian, Talebinejhad and Dastjerdi (2005) examined forty four randomly selected animal metaphors to compare in English and Persian to see if certain animal images were interpreted differently in the two languages. Findings made it clear that some animal images were entirely different so that no link could be found between their image in Persian and the corresponding image in English. Turtle, ostrich, bee, and shark werementionedas good examples to show clear cases of how variable the relation between metaphor and cultural models could be. They maintained that the differences between animal images in two languages were due to difference in users' cultural and personal experience. "When comparing a metaphorical expression in two languages, people are likely to attribute their own cultural interpretations to the ones not found directly in their mother tongue" (Talebinejhad/Dastjerdi 2005: 146).

In the same year, Olateju (2005) investigated animal metaphors in Yorùbá language with the intent of highlighting their stylistic and communicative potentials. To this end, distinctive features of domestic and wild animals which led to their metaphorical interpretations were highlighted. The sources of the animal metaphors were in three areas of Yorùbá naming culture, animal habits and behaviors, and Yorùbá poetry. The results showed that animal metaphors transferred meaning and meanings or interpretations assigned to a particular animal metaphor were culture and context dependent.

In another study, Shih (2006) analyzed animal-based metaphorical expressions of the Chinese Zodiac applied to men and women in Mandarin Chinese. The data were collected from a questionnaire distributed among undergraduate students at Providence University. The results of the study indicated that animal-based metaphorical expressions were of two-level (Animals are People and People are Animals). That is, the attribute of human beings is mapped onto the animals, the target domain, and the attribute mapped into the animals is mapped back to the human beings. The study also found that in general, when used to describe people, the use of these animal metaphors conveyed negative connotations.

In a study on animal metaphors, Kieltyka and Klepaski (2007) tried to shed more light on the scope of Chinese zoosemy, mainly on the basis of animal terms related to the conceptual category of DOMESTICATED ANIMALS. The findings revealed that the animal kingdom was one of the richest areas of metaphorical expansion and that most of the cases of animal metaphor were projected at the conceptual category of HUMANS.In their terminology, "animal metaphor fulfils both semantic and sociolinguistic functions in human communication" (Kieltya/Klepaski 2007: 96). They also maintained that "the process of zoosemy mirrors human relations and the way we assess society's demands and moral values and expectations set upon us and, in this sense, social/ aesthetic/behavioral and moral values and norms are manifested in our choice of as well as use of animal metaphors" (ibid.: 97). In a more recent study, Irene López Rodríguez (2009) conducted a study on animal images used for women in both English and Spanish. Findings indicated that an inferior social role was ascribed to women in both languages through the use of animal imagery. She believes that theses animal metaphors make people linguistically socialized and imposes patriarchal views about the role of women in society.

Metaphors reflect human values and the way they think about individuals and their relations. They originate from the social context and the surrounding environment. As can be seen from the literature, few studies have explored the positive/negative or praising/degrading aspect of 
animal expressions in different languages. Also, the extent to which domestic or wild animal metaphoric expressions dominate in different languages seems to be a relatively less attended topic. The available literature also indicates that very few, if any, studies have explored the animal metaphoric system in Iranian culture or in local varieties of several languages spoken in Iran. Such a gap provides strong motivation to investigate this area of research in an Iranian context. Since metaphor usage and interpretation in Iranian society may also be culture-bound, this study only takes into account the metaphoric system of Kurdish language spoken in Ilam. Besides, to limit the scope of the study and since to the best of the researchers' knowledge regional and local varieties have hardly been touched upon, this study explores and examines Khezeli dialect as one local variety of the Kurdish language in Ilam.

\section{The Region underStudy}

Kurds are a big community of people who live in several countries like Iran, Iraq, Turkey, and Syria. In Iran, they live in Northwest and west part of the country namely Kurdistan, Kermanshah, Ilam, Hamadan, and West Azerbaijan. Ilamprovince is located in the Southwestern part of the country bordering Khuzestan province in the South, Lurestan province in the East, Kermanshah province in the North, and Iraq in the West. It is situated in the cold mountainous region of Iran at latitude of $33^{\circ} 38^{\prime}$ North and longitude of $46^{\circ} 26^{\prime}$ East. Although this city is surrounded by mountains, its climate is also affected by deserts from the West and South. This region presents a highly variable annual weather profile.Heavy showers or snow in the winter and dusty, hot, dry weather in the summer are typical for this region. This province is a rich land where a civilization was established about 5000 years ago. It has a very old history and is among the oldest Iranian regions, historically known as the ancient Elamite Empire. In Elamite and Babylonian inscriptions, Ilam is called Alamto or Alam which means 'mountains' or 'the country of sunrise'. The cities of the province are Ilam, Mehran, Dehloran, Dareh Shahr, Sirvan, Chardavol, Eyvan and Abdanan. Ilam is the capital city of the province.

Kurd people In Ilam city consist of several main tribes such as, Khezel, Arkawazi, Malekshahi, and Dehbalaie. Khezel is one of the big tribes whose people live in different places including Nahavand in Hamadan province, Qasre Shirin and Gilane Gharb in Kermanshah, Lurestan, Isfahan, and Shiraz provinces in Iran and Naserye, Baghdad, Mandali, Khanaqin, and Jesan in Iraq. Some of Khezel people live in Ilam city but a majority of them live in the cities of Sirvan and Chardavol. More specifically, they live in the north and northwest part of Ilam province. This area is surrounded by Qalaja and Khorrama mountains in the North, Bankul and Manesht mountains in the West, Qelarang Mountains in the South and Sirvan and Chardavol small plains in the East. Winter quarters include Meimak heights where people fed and raised their animals in the past and which border Iraq. Khezel has a population of about 200,000 in Iran. About 60,000 out of this population live in Ilam province, where the study was carried out, including the cities of Ilam, Sirvan, and Chardavol. Farming, animal husbandry and less often hunting were the primary occupation of most of these people because of their type of living as nomads. The rich soil has been suitable for agriculture and the mountains with variable weather and plants have been a good habitation for different varieties of animals. Therefore, people as farmers or hunters had contact with these animals and were acquainted with animals' behaviors and characteristics. Animals such as cow, chicken, sheep, and horse are among the domesticated and lion, leopard, and snake are examples of the wild animals of the area. The behavioral 
characteristics of these animals have been well known to people and metaphors from their characteristics have been formed. These metaphors have been used and appreciated in people's poetry and their everyday language.

\section{$4 \quad$ Focus of the Study}

Although metaphor use is common to all languages and cultures and its use is universal, its choice for interpreting the world may be culture specific (Liu 2002). Thus, it might be right to think that different cultures interpret the same matter or issue with different metaphors or it may be the case that metaphorical expressions used in a language serve as an indicator of the culture, the ways of thinking, beliefs, and the worldviews of its speakers. This is why as Harris (1985) notes, the same animal may be considered good for one culture and harmful for another. Since taking the meaning of one expression for another may lead to misunderstanding and to communication breakdown in intercultural or intracultural encounters, there is a need to familiarize language learners with metaphoric expressions especially those containing animal names and those which may cause serious communication failure. This issue is more serious when interlocutors belong to different cultures and/or when metaphors convey different connotations for language users.

Despite the large number of studies recently conducted in the area of metaphor, most of them have been based on English data and few, if any, attempts have been made to investigate the metaphorical system of Kurdish or Persian languages. Moreover, as Kövecses (2006) points out, within one culture variation may also exist due to social, regional, ethnic, stylistic, subcultural, diachronic, developmental, and individual dimensions. Accordingly, this study is intended to analyze animal expressions used in Khezeli dialect as a variety of Kurdish language of Ilam-Iran. More specifically, the study addressed domestic and wild animal metaphors and their usages to praise or degrade physical or behavioral characteristics of people through the following research questions.

1. How balanced is the use of wild/domestic animals in Khezeli dialect?

2. How are wild and domestic animal metaphors distributed to express praising and degrading functions?

3. How physical and behavioral characteristics are metaphorically mapped in Khezeli dialect?

4. To what extent are users' beliefs, ideas, or values reflected in their use of animal metaphors?

5. To what extent do animal names connote positive/negative characteristics?

\section{The Corpus}

In conducting this study, naturally-occurring animal expressions in the spoken discourse of Khezel people while communicating and their oral poetry were analyzed. The instances of metaphoric use of the spoken language of people have been gathered and recorded for a total of three years. This was practical since one of the researchers is a native speaker of the dialect living among these people. Two other sources of metaphoric language in spoken discourse known as Hura and Muye were also addressed. They are kinds of metaphor-saturated oral 
poetry which are used in almost all dialects of Kurdish language. They do not have known poets and are among folk songs. These oral traditions have been widely used and respected among Kurd people since ancient times and were also rich sources for collecting the required data. Recited and sung in happy moments and occasions, Hura includes a wide range of different themes such as life, death, youth, old age, physical and behavioral characteristics. Fulfilling a different function, Muye is also a kind of oral poetry with poems appreciating positive attributes such as courage of a dead person sung at his funeral.It iscommon that Khezel people tape record and memorize these poems. By analyzing the available tapes and recording the poems memorized by the old people, this source of data was also scrutinized for the adopted metaphors. And the last source for gathering the data was the oral poems of Wali Mohammad Omidi which were available on tape. Mr. Omidi whose pen name is Wali Bigana is a famous Kurd poet from Khezel tribe. He has recorded his poems on tape during his lifetime, but after his death a collection of his poems has been compiled and published by Yaser Sanaie (2008) under the title Poems of Wali Mohammad Omidi. A variety of themes are expressed in his poems, the most notable of which are the courage and heroism of Kurd warriors in fights against enemies, the valour of people from his tribe, the courage of great religious people, and descriptions of nature, natural elements and historical events. As Sanaie (2008) states, his poems can be classified as epics and are rich in the use of apostrophes, hyperboles, metaphors, similes, and allusions. Omidi has used different literary forms but the most salient one is couplet.By analyzing the recorded poems, the metaphorical expressions were elicited and analyzed. All together throughout the study 189 instances of metaphorical expressions were realized.

\section{Classification Scheme}

To answer the aforementioned research questions and to draw conclusions out of the collected data, a classification scheme was designed. Accordingly, metaphors were first grouped under two major categories of appearance and behavioral metaphors. Depending on whether they referred to body organs or one's overall figure, appearance metaphors were further classified into bodypart metaphors and whole body metaphors. Under every heading, examples for metaphor function (praise/degrading) as well as the types of the animals (wild/domestic) are provided. Praising metaphors are presented prior to degrading ones and examples of wild animal metaphors are provided before those of domestic animals.

Behavioral metaphors were also divided into four categories according to the same criteria; wild animal metaphors for praising, domestic animal metaphors for praising, wild animal metaphors for degrading and domestic animal metaphors for degrading. Since the number of metaphoric expressions is large, a complete list of 189 instances is given in the appendix and only one example is given after each heading in the text. In general, the developed scheme led to twelve possible categories of animal metaphors. For the ease of referencing and discussion, they are labeled with capital letter from A to L. 


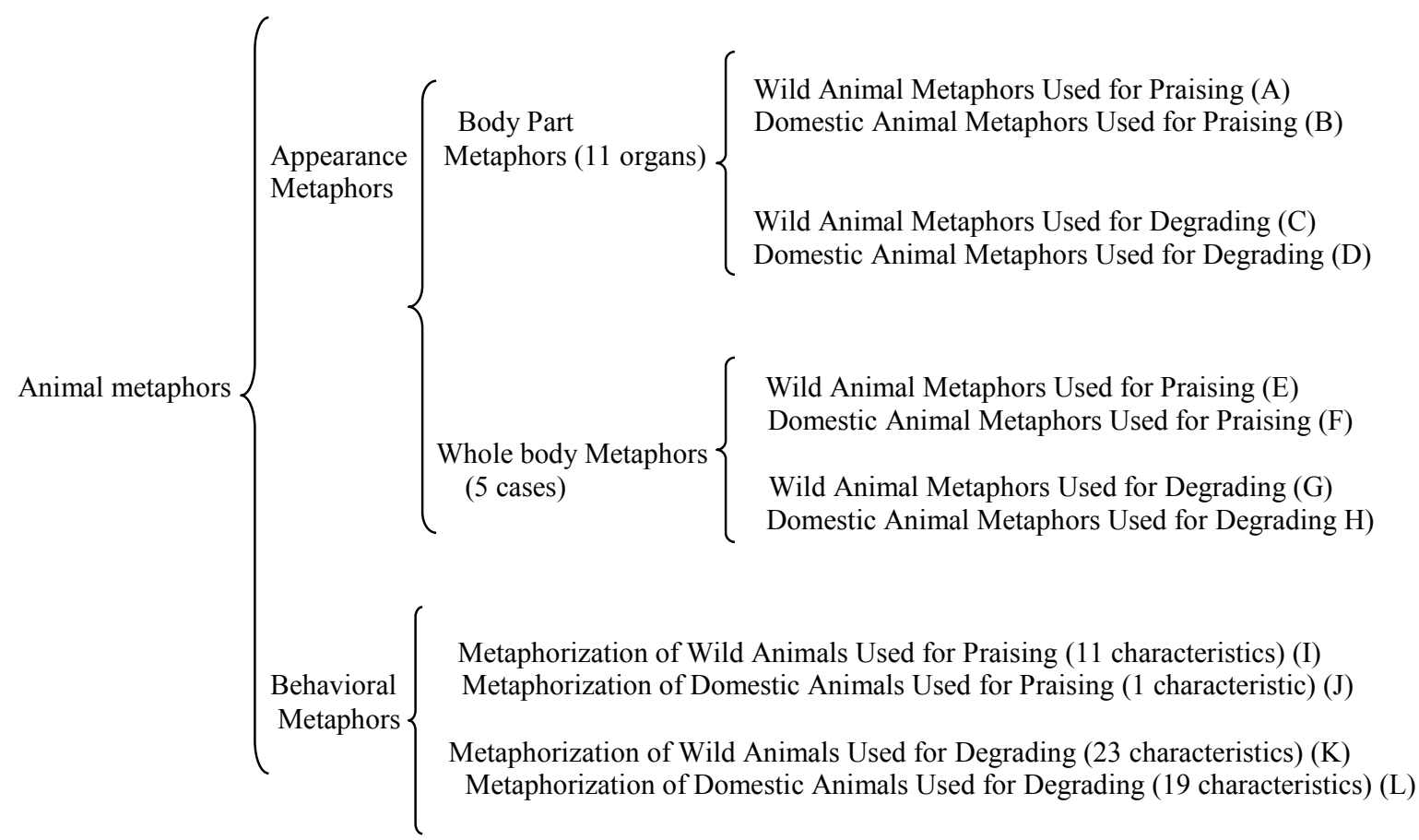

Figure 1: Schematic representation of the classification of animal metaphors in the study.

To clarify the users' meaning, the literal translations of the metaphoric expressions and the original quotes are provided. The figurative sense of the expressions in Khezeli dialect is also provided in the parentheses following the expressions. It is worth mentioning that explanation of the collected metaphors was elicited from people who used them.

\subsection{Appearance metaphors}

A good number of metaphors referred to the appearance or physical attributes of a person. Appearance includes either reference to certain organs or parts of the body or the overall size and overall physical characteristics of a person. In the sections that follow instances of metaphoric expressions for eleven organs and five major categories for whole body metaphors are addressed.

\subsubsection{Body part metaphors}

This section is devoted to the presentation of some of the instances of metaphoric expressions referring to body parts. Under this heading, examples of metaphors for eleven organs or body parts including hair, eye, nose, lip, tooth, chin, ear, neck, head, hand, and leg are presented.

\subsubsection{Hair metaphors}

In Khezeli dialect, for the description of one's hair as the target, five animal names were found at use. Snake, scorpion and raven were three wild animals that were metaphorically used to praise one's hair.No domestic animals were realized for praising one's hair, nor were any wild animal expressions for the degradation of one's hair.Goat and mule were two domestic animals, expressions of which were used for degrading one's hair.

Her/his hair is a bald goat's hair, بزن كه 2 (to degrade a person who has lost his/her hair). 


\subsubsection{Eye metaphors}

Twelve metaphors described human eyes. In the corpus, Hawk, gazelle, and deer were three wild animals used for praising one's eyes.Ox is the only domestic animal used to praise one's eyes. Mole, cat, Salamander, frog, and owl were five wild animals used for degrading human eyes.Donkey, chick, and whelp were three domestic animal names found in degrading metaphors.

Cat-eye, ششى جيه م (refers to small blue eyes).

\subsubsection{Nose metaphors}

In the corpus, six metaphors were identified for describing one's nose. No wild animal metaphors were found. Ram was the only domestic animal name used for praising human nose. Out of the five degrading metaphors, monkey, eagle, and raven were the three wild animal names. Two other degrading metaphors were expressions including the name of the domestic animals of cow and mule.

Ram-muzzle, وهرهن (rogefers to a beautiful nose).

\subsubsection{Lip metaphors}

Pearl-oyster was found to be the only praising animal metaphor.No domestic animals were found for this function.No wild animals were used to degrade one's lip. Camel and cow were two realized degrading metaphors describing one's lip.

Pearl-oyster lip, ليّو س مده في (refers to thin lips).

\subsubsection{Tooth metaphors}

Elephant was the only wild animal name used in metaphoric expressions for praising the human tooth.Warthog and mouse were two wild animal names metaphorically used to degrade one's tooth.Donkey was the only domestic animal used for the degradation of one's tooth.

Mouse-tooth, ميووش دنان (refers to very small teeth).

\subsubsection{Chin and mouth metaphors}

Warthog, monkey, frog, and wolf were four wild animal names metaphorically used to degrade one's chin. Mule and whelp were two domestic animals realized for degradation of one's chin.

Monkey-chin, ميموون ده (refers to a very unpleasant chin).

\subsubsection{Ear and hearing metaphors}

Four metaphors described one's ears or sense of hearing. Snake, deer, and mouse were three noted wild animal names used for praising. Mule was the only degrading domestic animal name used in degrading metaphors.

He/she has mouse ear, كووشيَ مه نكه كووش ميووش (refers to the sharp sense of hearing). 


\subsubsection{Neck metaphors}

Throughout the corpus, ten metaphors were found for describing one's neck. Deer was the only wild animal adopted for praising one's neck.Giraffe, frog, goose, vulture, warthog, and monkey were six wild animals, metaphors from which were used for degrading one's neck.Camel, turkey, and donkey were three domestic animals whose expressions contained negative connotations for describing human neck.

Giraffe-neck, زمرافه مل (refers to a very long neck).

\subsubsection{Head metaphors}

Throughout the study, for describing one's head or face eleven metaphors were identified. Lion and elephant were two wild animal names which carried a positive sense for describing one's head. No domestic animal names were found to praise one's head. Partridge, owl, Lark, chameleon, and sparrow were five wild animals that transferred negative connotations when used metaphorically. Donkey, dog, hen, and chick were four domestic animal names found in negative metaphoric expressions related to the head.

Chameleon-head, قوم قو مه ك سه (this type of lizard lives in mountainous areas and has an unpleasant small head. Its metaphor connotes an ugly small head).

\subsubsection{Hand metaphors}

Only five degrading metaphors were observed for describing human hands. Hedgehog, monkey, crab, bear, and leopard were the wild animals transferring negative connotations when used metaphorically. No praising animal metaphors were found, nor were domestic animal names used for degrading people's hands.

Crab-hands, ده س قر جنظى (refers to rough, coarse hands).

\subsubsection{Leg metaphors}

Seven metaphors described human legs. Elephant and deer were two wild animals used to praise one's leg.No domestic animals were found to describe the human leg positively. Leopard, bear, and hedgehog were three wild animals realized for the degradation of one's leg.Mule and goat were the two domestic animals used to disparagingly describe one's leg.

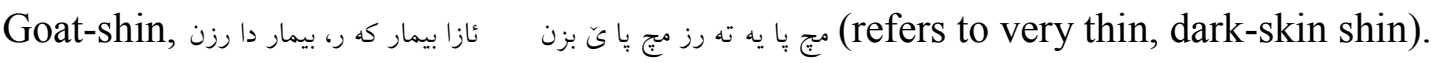

\subsubsection{Whole body metaphors}

As mentioned earlier, the metaphors adopted for describing the physical characteristics of people were classified into those referring to body parts and those used for the whole-person's appearance. In the following section, five categories of whole body metaphors, which connote one's figure, beauty, ugliness, thinness, and fatness, are presented.

\subsubsection{Figure metaphors}

Analysis of the corpus showed that for the description of one's figure, five metaphors existed. Eagle, deer, and fish were three wild animals which were positively used. However, no 
domestic animal metaphors were found. Giraffe and hound were two wild animal names used to disgrace one's figure. No domestic animals were found.

What a blondeagle, دآ هيوول (refers to very handsome, blond person).

\subsubsection{Metaphors for beauty}

Beauty metaphors are usually used for females.In this relation, four metaphors of wild animal names were recognized. Partridge, gazelle, swan, and pea-hen were the animal names used to praise a woman's beauty. No domestic animal names were realized throughout the study.

Oh, the pea-hen lady, هئ، تاووس خانم (refers to the utmost beauty of a woman).

\subsubsection{Metaphors for ugliness}

When talking about one's ugliness in Khezeli dialect, people tended to use six different metaphors.Fox, hedgehog, jackal, monkey, frog, and crocodile which are all wild animal names were metaphorically used for this function.

Fox burnt in the jungle, وووى يه قورق سزيا (refers to a very unattractively dark and slim person).

\subsubsection{Metaphors for thinness}

Describing one's thinness, people used three metaphors which were all degrading. It seems that users of this dialect do not appreciate thinness. Yellow centipede and yellow snake were the two wild animals, metaphors of which were used for degrading one's thinness. Chick was the only domestic animal name used in negative metaphoric expressions for degrading thinness.

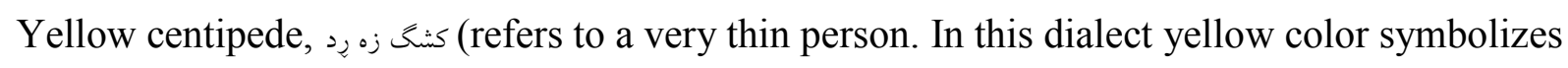
one's thinness and weakness).

\subsubsection{Metaphors for fatness}

Warthog, bear, and rat were three wild animal names used to degrade one's fatness.Cow is the only domestic animal used in negative metaphoric expressions for fatness.

She/he is a big cow/ox, كَائ سه ين (refers to a fat person).

\subsection{Behavioral metaphors}

In Khezeli dialect people tend to relate how an animal behaves, the way it moves, eats, and fights, its manner of living, sleeping, walking, running, etc. to human characteristics. They ascribe a certain action to an animal. It looks as if the image schemas of animals are stored in people's minds and when somebody performs a similar action the metaphor is used to describe what the person is doing. For example, lion invades other animals' territory courageously and hunts them with no fear and thus is famous for its bravery. This characteristic is transferred to a person who fights without fearing anything. In the sections that follow four categories of metaphoric expressions for the description of one's behavior are introduced. Wild/praising, domestic/praising, wild/ degrading, and domestic/degrading animal metaphors are presented in order. 


\subsubsection{Metaphorization of wild animals used for praising}

The first category pertained to the recognition of wild animal metaphoric expressions used for praising one's behavior. In what follows instances of this categorization for eleven respected human attributes including those used for a quick person, a light sleeper, a very intelligent person, a good tempered person, a good voiced person, a person with soft words, a content person, a powerful or strong person, a brave person, a humble, shy or polite person, and a person with long-term memory are presented along with their interpretations or explanations in parentheses.

A quick person is one who has the most salient feature of quickness found in hound, rabbit, tarantula, gazelle, hawk, and dull-yellow-partridge.

You tarantula, جئيله (this animal is also very quick and runs fast).

A light sleeper is mostly linked to a partridge.

Her/his sleep is a partridge's nap, كو كه مخاو (this animal wakes up with a very slight or soft noise or sound).

A very intelligent person is associated with the wild animal deer.

She/he is a deer ahead of stampede, شكارئ نوائ حه م (it refers to the characteristic of the animal which cares for every small sound, smells every smell and reacts quickly for the fear that they may come from her enemies).

A good tempered person is linked to a turtledove.

A good-tempered turtledove, قو مرى خوه ش اخلاق (people consider this bird as a kind bird because it does not hurt any other creatures).

A good voiced person has characteristics found in partridge and nightingale.

Her voice is a partridge's singing, شاقه يَه ما يَخ (partridge sings sweetly, especially in spring).

A person with softwords is a parrot.

A soft word parrot, تووتى شيرين زوانيّكه (it refers to the special capability of this animal that can be trained to copy human speech like a young child whose speech is a lovely repetition of his parents').

A content person has a snake-like characteristic.

The not eating anything snake, ئرا مارم وه خه حق قانئ بووم (it is said that this animal does not eat anything in winter).

A powerful or strong person is associated with the wild animals, leopard, tiger, and elephant.

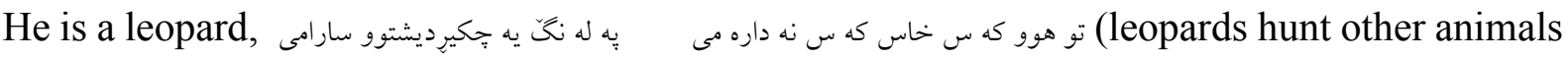
and are very strong in fighting).

A brave person is described as a lion. 


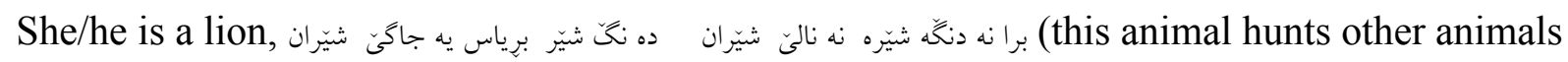
and is said not to fear any other animals).

A humble, shy or polite person is linked to a leopard or a raven.

She/he is a shy leopard, شه رميّ به له نحّ ديّرى (contrary to other animals, leopards do not couple when others are present).

A person with long-term memory is like a raven.

I don't have the raven's memory, هيوور قلّا نيرم (ravens have very excellent memories; they easily remember the places where they hid the things they had stolen long ago).

\subsubsection{Metaphorization of domestic animals used for praising}

This category is to embrace the presentation of the instances found for praising one's behavioral characteristic when the source domain is a domestic animal name. Throughout this study only one instance was found to map this function.

Honesty is the most salient feature found in the domestic animal sheep. Thus, an honest person is likened to a sheep (it refers to the calmness of sheep).

She/he is a prophet's sheep, مئ يَّخه م به ريَّكه (it refers tothebehavior of the animal which is very calm. The use of the collocation prophet sheep transfers the idea of sheep's honesty. Moreover while grazing, unlike goats, sheep do not eat their shepherd's food).

\subsubsection{Metaphorization of wild animals used for degrading}

Following the classification of the behavioral characteristics into four categories, the third category includes the instances collected for the degradation of one's behavior when the source domain is a wild animal name. The results of this categorization for twenty three undesirable human attributes include expressions used to describe people who are weak, a heavy sleeper, taciturn, a big eater, a small eater, bad tempered, shrewd, grumbling, cunning, cruel, unlucky, bad voiced, rush, meddlesome, obstinate, shameless, coward, greedy, covetous, dirty, or talkative.There were also animal expressions for those who stay awake at night, and people with sharp tongue.

A weak person is mostly associated with owl.

Look at this owl, بيويَّك (it refers to the behavior of the animal that most often is silent and does not move. It merely hunts small animals mostly at night and it does not fight other animals).

A heavy sleeper islikened to a bear.

The sleepy-head bear, خر س خاوالو (it refers to the behavior of the animal that sleeps during winter).

A taciturn person is an owl.

The taciturn owl, بيوو مه كوويكَّه (it refers to the behavior of the animal that is most often silent and rarely makes any sound).

A big eater person is like the wild animal snake in that its belly is never protruded. 
Snake-belly, مار ز3 (it refers to a person who eats a lot but his/her belly is not fat).

A small eater person eats like a sparrow.

She/he sparrow-eats the food, مه ليوو تخ خوهر غه ذا مه كئ (it refers to the behavior of the animal that eats a little).

A bad tempered person is likened to a hedgehog, snake or wolf.

Her/his tongue is snake's venom, مه نكة زه هر مار (the bitterness of the venom of the animal is likened to the bitterness of a bad-tempered person).

A shrewd and astute person is likened to some of wild animals including lizard, mouse, and centipede.

She/he is a lizard, هي مارميوولى (it refers to the behavior of the animal which scuttles into every hole).

A grumbling person is a fox or a bear crying from pain.

The groaning-fox, 2ووى زان كردين (it refers to the behavior of the animal that groans from stomachache).

A cunning person is the wild animal fox, jackal, or an old wolf.

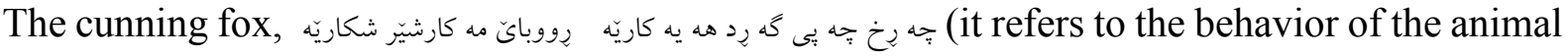
that hunts with trickery since it hides itself and waits until its victim arrives. It does not have the power to fight big animals and eats only small animals).

A cruel person behaves as if she/he is a wolf, cat or an ant.

What a wolf, كور كان به عسى مه كيشان زوزه خزل سووره ت يه ك ميّان بووسه (it refers to the behavior of the animal that kills the whole cattle when hunting).

An unlucky person is linked to a number of wild animals including raven, owl, and rabbit. They are known as messengers of unhappiness since ancient times.

She/he is an unlucky owl, جوقد شووم (this refers to the behavior of the animal which lives in ruined and quiet places. In people's view, the animal and the places it lives in are symbols of misfortune).

A bad voiced person is like the wild animal bear.

Keep your bear-voice down, خرس بوولن، بووله د باره خوار (people believe that bear makes unpleasant sounds).

A rush person isequated with monkey.

You, monkey, ميموون (it refers to the behavior of the animal that jumps quickly and hastily from one tree to another).

A meddlesome person is linked to a raven, hoopoe or an ant. 
Stop meddling! The hoopoe, بازه ح حه زره ت عن سليّمان كه مزوولى بكه (it alludes to the hoopoe of Solomon the Prophet to whom she brought news).

An obstinate person is likened to a warthog.

The fixed-neck warthog, وراز ين كرىن مل (it refers to the characteristic of the animal that can only move in a direct line and cannot move its head; an obstinate person also moves in his/her own way).

A shameless person acts like a wolf, sparrow, and she-wolf.

She is a she-wolf, ده له كور كيّيكه (people attribute the characteristic of this animal to a person who shamelessly and cruelly does everything to achieve her goals.)

A coward person's behavior is likened to a timid partridge.

There is no partridge flapping in his/her heart, يرت كق يه دلي نيه (partridge is famous for its cowardice and this metaphorical expression refers to a person who is easily frightened, even by flaps of partridge's wings; a coward who is frightened by a coward).

A greedy person is associated with amouse or a wolf.

A loss-making mouse, ميووش زيان كه ر (when it attacks a stock of grain, it eats from all parts of the stock and makes it dirty).

A covetous person is one who acts like a vulture.

Look at this vulture near the dead corpse, دال ديار له 2) (it refers to the behavior of the animal that eats the remainder of other animals' victims).

A dirty person is the one who is mostly like a pig or a warthog's cub.

Oh, dirty pig, خووك بيّس (in the Islamic tradition pigs are considered unclean).

A talkative person is one who cries like a hyena.

Stop crying! The crying hyena, كه م بقلنّن (it refers to the behavior of the animal thatmakes sounds most of the time without any reason. This metaphor refers to a person who talks a lot meaninglessly).

A person who stays awake at night is also likened to an owl.

Sleep, owl, بايّه قوز بخه ف (this refers to the behavior of the animal that is awake all the night).

A person with a sharp tongue is related to a scorpion or snake.

Her/his tongue is a scorpion's sting, زواني نيشي ئه قروه (a scorpion's sting is fatal. A person with a sharp tongue also annoys and kills others spiritually by his or her words).

\subsubsection{Metaphorization of domestic animals used for degrading}

The last category deals with the recognition of metaphoric expressions used for degrading one's behavior with features of a domestic animal. The nineteen unappreciated human characteristics for this section include those used for a slow, a restless, a cruel, a stupid, a weak, a low spirited, 
a thoughtless, a revengeful, a bad tempered, a big eater, a small eater, a shameless, a worthless, a bad voiced, a proud, an obstinate, an unpunctual, a dirty, and a talkative person.

A slow person is likened to a cow, a broody hen, or a lame donkey.

خه شه J,The lame donkers to the behavior of the animal that is not able to walk correctly because of physical injury to or weakness in its legs or feet).

A restless and anxious person is likened to a hen in the following metaphor.

She/he is a flapping hen, مرخ سه ربيا (it refers to the behavior of the animal that shakes its wings repeatedly when its head is cut).

A cruel person is most often associated witha dog.

You rabid dog, سه كار (a rabid dog bites and attacks everyone).

A stupid person is linked to certain domestic animals such as a donkey, sheep, a cow, a packhorse, or a turkey.

Confused sheep, (it refers to the behavior of the diseased sheep which is always confused. Confusion is a kind of animal disease).

A weak person is likened to a kid or a chick.

Last hatched chick, جيوو جکى دمالان (nothing remains for the last hatched chick because the earlier hatched chicks have eaten everything; it often dies from weakness).

A low spirit person is assimilated into a hen.

Blue-crest-stricken hen, مامر يوويكه كق كردئ (blue crest is a kind of disease because of which the crest becomes blue. A blue-crest suffering hen loses her freshness and health and tends to detach herself from the rest of the group).

A thoughtless person acts like a cow.

You, the thoughtless cow/ox, كا، بره سئو (it refers to the behavior of the animal which moves slowly in time of danger).

A revengeful person is likened to a camel.

She/he is a revengeful camel, كينه شترى (it refers to the behavior of the animal that is thought to remember even a bit annoyance done to it and revenges the person who has done so).

A bad tempered personor a naughty child isassimilated intoa dog, a mule, or a horse.

She/he is a vicious mule, قاتر خه ميووش (a vicious mule always kicks, it refers to a naughty child).

A big eater person is likened to a cow / ox.

The big-eater cow/ox, كائ فره خوه ر (this animal eats a lot).

A small eater person is associated with a chick. 
The small-eater chick, جيوجگ هيووت مه خو ه (it refers to the behavior of the animal which eats a little).

A shameless person is linked to a dog or hen.

You are inattentive to shoo, كش مه زان (refers to the behavior of hens that do not care about human shooing).

A worthless person is most often associated with an old mule or a dog.

Not barking dog بـ (a dog is only useful when it barks on time. Whenever a dog does not bark in due time, it is worthless).

A bad voiced person has a sound like a donkey.

Stop braying, كه م بسه رن (people believe that donkey has an unpleasant sound).

A proud and arrogant person behaves like a cock or dog.

The arrogant cock, كلَه شير قوت (it refers to the behavior of the animal that holds its head and neck in an upright manner and walks proudly).

An obstinate person is a donkey.

The obstinate donkey, خه ر له جووج (it refers to the behavior of the animal which tries to move ahead if another donkey is also going to carry its load in the same direction).

An unpunctual person is a cock.

You unpunctual cock, كلَ شيَر نه وهوهت (it refers to the behavior of the animal that crows untimely).

A dirty person is most associated with a dog or goat.

You dirty dog, سه ك بئس (it refers to the Islamic tradition in which dogs are considered unclean).

A talkative person is linked to a dog.

She/he always barks, ثقه پِاس مه كه (it refers to a dog that barks most of the time without any reason or meaning, it refers to a person who talks nonsense).

\section{$7 \quad$ Results}

Observing the classification scheme explained earlier, the data collected from the corpus are presented in Table 1. 


\begin{tabular}{|c|c|c|c|c|c|}
\hline \multirow{12}{*}{$\begin{array}{l}\text { Animal } \\
\text { metaphors }\end{array}$} & \multirow{8}{*}{$\begin{array}{l}\text { Appearance } \\
\text { Metaphors }\end{array}$} & \multirow{4}{*}{$\begin{array}{l}\text { Body Part } \\
\text { Metaphors }\end{array}$} & $\mathrm{A}$ & $\begin{array}{l}\text { Wild Animal Metaphors Used } \\
\text { for Praising }\end{array}$ & 16 \\
\hline & & & $\mathrm{B}$ & $\begin{array}{l}\text { Domestic Animal Metaphors } \\
\text { Used for Praising }\end{array}$ & 2 \\
\hline & & & $\mathrm{C}$ & $\begin{array}{l}\text { Wild Animal Metaphors Used } \\
\text { for Degrading }\end{array}$ & 33 \\
\hline & & & $\mathrm{D}$ & $\begin{array}{l}\text { Domestic Animal Metaphors } \\
\text { Used for Degrading }\end{array}$ & 22 \\
\hline & & \multirow{4}{*}{$\begin{array}{l}\text { Whole body } \\
\text { Metaphor }\end{array}$} & $\mathrm{E}$ & $\begin{array}{l}\text { Wild Animal Metaphors Used } \\
\text { for Praising }\end{array}$ & 7 \\
\hline & & & $\mathrm{F}$ & $\begin{array}{l}\text { Domestic Animal Metaphors } \\
\text { Used for Praising }\end{array}$ & 0 \\
\hline & & & G & $\begin{array}{l}\text { Wild Animal Metaphors Used } \\
\text { for Degrading }\end{array}$ & 13 \\
\hline & & & $\mathrm{H}$ & $\begin{array}{l}\text { Domestic Animal Metaphors } \\
\text { Used for Degrading }\end{array}$ & 2 \\
\hline & \multirow{4}{*}{\multicolumn{2}{|c|}{ Behavioral Metaphor }} & I & $\begin{array}{l}\text { Wild Animal Metaphors Used } \\
\text { for Praising }\end{array}$ & 20 \\
\hline & & & $\mathrm{J}$ & $\begin{array}{l}\text { Domestic Animal Metaphors } \\
\text { Used for Praising }\end{array}$ & 1 \\
\hline & & & $\mathrm{K}$ & $\begin{array}{l}\text { Wild Animal Metaphors Used } \\
\text { for Degrading }\end{array}$ & 41 \\
\hline & & & $\mathrm{L}$ & $\begin{array}{l}\text { Domestic Animal Metaphors } \\
\text { Used for Degrading }\end{array}$ & 32 \\
\hline
\end{tabular}

Table 1: Frequency of Metaphors According to the Classification Scheme

\section{Discussion}

The first research question intended to find out about the dominance of wild or domestic metaphors in the dialect under study. The data indicated that in Khezeli dialect people generally prefer to use wild animal metaphors twice as often as domestic animal metaphors. This is also true for almost all classes of metaphors.

Concerning the second research question presented to check people's preference for using degrading/praising metaphors, it was revealed that 143 metaphors $(\mathrm{C}, \mathrm{D}, \mathrm{G}, \mathrm{H}, \mathrm{K}, \mathrm{L}$, table 1) were used to degrade people, while only 46 metaphors (A, B, E, F, I, J, table 1) were used to praise people. Thus, the data represented more degrading metaphors.

In response to the third research question, the study further indicated that for speakers of Khezeli dialect, animal names were mapped to both the description of body organs and whole body appearance.In this dialect metaphors with different source domains were found to map onto the same target domain. That is, for one physical or behavioral characteristic more than 
one animal metaphor was used. For example, to describe one's ear (physical characteristic) three animal metaphors were collected in this dialect (see the appendix).

a. His/her ear is a snake's ear (37)

b. His/her ear is a deer's ear (38)

c. His/her ear is a mouse's ear (39)

Similarly, when the behavioral characteristic of quickness was to be described, hound, rabbit or gazelle might be referred to.

d. She/he is a hound (96)

e. She/he is a rabbit (97)

f. She is a gazelle (99)

Close examination of the observed instances indicated great flexibility of animal metaphoric construction in this dialect. As a result, the same animal may be used in a variety of ways for describing different physical or behavioral characteristics. Examples include deer.

g. Deer-eyes ( refers to beautiful eyes, 8)

h. Her/his ear is a deer's ear ( refers to both beauty an sense of hearing, 38)

i. Deer-neck ( refers to a nice neck, 41)

j. Her shin is a deer's shin ( refers to nice long shins, 68)

k. Look at this deer ( refers to a lovely figure, 75)

1. She/he is a deer ahead of stampede (refers to a very intelligent and quick person, 103)

An interesting finding is that one particular animal may be used for both praise and degradation of behavior and physical characteristics of a person.Examples of such a case include raven.

m. Black-raven hair ( used for praising one's black hair, 3)

n. Raven-nose ( used to degrade one's nose, 21)

o. She/ he is a shy raven ( used to praise the behavior, 114)

p. She/he is an unlucky raven ( used for degradation of this behavior, 136)

q. She/he is a meddler raven (used for degradation of this behavior, 141)

Analysis of the results for the fourth research question also led to several interesting findings. People of this tribe tend to consider yellow as the color which symbolizes one's thinness or illness and they have reflected this idea in their metaphors ( $89 \& 90)$. Another example is found in the metaphor black rabbit (138) where the black color symbolizes the bad omen the animal brings about. They also believe that everyone should respect old people and anyone who violates this norm is considered rude, shameless or impudent. This is also projected onto their metaphors (173\& 178). They also attribute an animal's illness to its dirtiness (188).People's belief in Islam and its orders has also reflected itself in people's metaphoric expressions. For example, they consider pigs and dogs as unclean (152 \& 187). So, it can be claimed that people's beliefs, values, and ideas reflect themselves in their language. 
As for the last research question, the study uncovered more interesting findings. It was revealed that in Khezeli dialect, based on their evaluations, people had three categories of animals in their minds. These categories were realized during the analysis of the data. The first category includes animals which are always used in a positive sense. These animals are referred to for praising one's physical or behavioral characteristics. This category includes hawk, parrot, nightingale, turtledove, dull-yellow-partridge, swan, peahen, gazelle, deer, pearl-oyster, elephant, lion, fish, tarantula, tiger, and ram. What is interesting about these animals is that except for ram, all other animals (15 animals) of this category are wild animals. Thus, it can be concluded that positive attributes are (almost always) found in wild animals. The second category included animals which were used to refer to both positive and negative aspects and attributes. In other words, the same animal was used for praising certain characteristics and the degradation of other attributes. This group includes, eagle, mouse, partridge, leopard, raven, snake, hound, rabbit, scorpion, sheep, and ox. Except for sheep and ox, other animals (9 animals) belonging to this category are wild animals. The third category relates to animals which are always used in metaphors with negative connotations. These animals are always used for the degradation of physical or behavioral characteristics of individuals. Mole, ant, salamander, frog, owl, monkey, wolf, crab, warthog, giraffe, goose, vulture, lark, chameleon, hedgehog, bear, fox, jackal, crocodile, yellow-centipede, rat, lizard, cat, hoopoe, hyena, warthog's cub, pig, sparrow, whelp, goat, mule, donkey, pack-horse, chick, hen, cock, turkey, dog, kid, cow, and camel belong to this category. Except for the last 13 animals the other animals (28 animals) are wild animals. Further notice to the third category showed that for negative attributes both wild and domestic animals are used but the number of wild animals is higher than domestic animals, Table 2 presents the results.

\begin{tabular}{|l|c|c|c|}
\hline \multirow{2}{*}{ Animal categories } & \multicolumn{2}{|c|}{ Class of animals } & \multirow{2}{*}{ Sum } \\
\cline { 2 - 4 } & Domestic & Wild & \\
\hline Always used in Positive sense & 1 & 15 & 16 \\
\hline Used in both Positive/ negative sense & & & 11 \\
\hline Always used in Negative sense & 2 & 9 & 41 \\
\hline Sum & 13 & 28 & 68 \\
\hline
\end{tabular}

Table 2: Representation of Positive/Negative Connotation of Animal Names in Metaphors

\section{Conclusions}

Since ancient times and as a result of close contact and keen observation of domestic and wild animals, man has acquired a good knowledge of these animals. Accordingly, their behavioral and physical characteristics have widely been the focus of people's attention and people reacted both appreciatively and disrespectfully toward animal behaviors. This is why from long ago human beings have been compared to animals and people often express their feelings toward an individual by animal metaphoric expressions. 
Throughout the study, a corpus of 189 metaphors (with the exclusion of the repetition of the same animal names used in different metaphors for the same characteristic) was examined and classified under four wild/praising, domestic/praising, wild/degrading, and domestic/degrading categories. Findings of the study indicated that, for Khezeli dialect, both wild/domestic and praising/degrading animal expressions were used in describing one's physical and behavioral characteristics. The vast number of the examples found in the corpus, showed that in line with Lakoff and Johnson (1980) (target domain is source domain), HUMANS ARE ANIMALS metaphor exists in this dialect. To be more precise, the findings showed that for the description of an individual's body parts or behavior, both praising and degrading metaphors with wild and domestic animals were used to project a feeling onto the hearer.

With reference to the first research question, it could be concluded that people tended to use more wild animal names in their metaphors to characterize people's physical and behavioral characteristics. This finding is not consistent with Thornton (1989), Kleparski (2002), and Kieltyka and Kleparski (2007) who claim that people most often tend to apply the names of those animals to which they are the closest and/or most familiar to other individuals. In other words, due to their regular closeness to people, domesticated animals are expected to be a category particularly and richly represented in metaphorical expressions in various languages and cultures. Yet, in the current research context, the transferred culture of the ancestors' style of living as nomads in earlier times may account for their familiarity and use of a wider range of wild animals than domestic animals.

Answer to the second research question of the study uncovered that humans were associated more with animals with a degrading aspect attached to them. This finding is in line with Kövecses (2002) and Talebinejad and Dastjerdi (2005) who maintain that most animal metaphors express negative characteristics of human beings. The results of the study carried out by Shih (2006) on animal-based metaphorical expressions in Mandarin Chinese also showed that in general the use of these animal metaphors when used to describe people, conveyed negative connotations.

Based on the quantification of the results of the study, it can be asserted that wild animals (52 wild vs. 16 domestic animals, table 2), and wild animal metaphors (130 wild vs. 59 domestic animal metaphors, table 1) dominate in the dialect under study. Besides, more undesired animals (41 negative vs. 16 positive, table 2 ) and more degrading metaphors (143 degrading vs. 46 praising, table 1) are used in Khezeli dialect.From the above assertions, there is evidence to claim that in the dialect under study HUMANS ARE UNDESIRED WILD ANIMALS.

Although the use of degrading metaphors was dominant in the dialect, the study indicated that certain animal metaphors were always used to convey positive characteristics of people. Conspicuous examples included lion (a brave person), gazelle (a quick person) and peahen (a beautiful lady). This contrasting use of animal metaphors to praise has been justified by López Rodríguez (2009) when she acknowledged that positive value reflects cultural views. In her terms "Indeed, the attitudes held by the members of a community towards particular animals may be responsible for endowing the animal name with either positive or negative implications"(López Rodríguez 2009: 81).

Results of the third research question uncovered that in praising or degrading one's appearance, overall size, overall physical characteristics as well as the body parts of both wild and domestic 
animals were transferred to humans. Examples of such findings can be noted in cow (ox) fatness (in 95) or Whelp-eye (in 17). Appearance in the dialect investigated was found to be like the English pattern in Ahrens and Say (1999). Put in different terms, both overall size and body parts were allowed to map from the source to the target domain. The dominant realization was unlike the Chinese pattern explained in Ahrens and Say in that only body parts were allowed to map in Chinese.From another perspective, the findings are like Mandarin Chinese animal expressions in Ahrens and Say's (1999) study in that the appearance of an animal is usually mapped to the target domain of human appearance, whereas animal behaviors are mapped to human behaviors. Moreover, there were several cases in which different meanings were attributed to the same behavior of an animal. Examples included: raven in 136 and 141, wolf in 133 and 150, dog in 173 and 178. And less often for the description of a certain behavior or a physical attribute, one animal name was expressed in several metaphors with different terminologies but near in meaning. Examples included degrading one's hair in 4 (a, b, c), reference to bad temperedness by means of certain aspects of snake in $123(a, b)$, reference to a partridge's cowardice in $148(\mathrm{a}, \mathrm{b})$, reference to a dog's cruelty in $162(\mathrm{a}, \mathrm{b})$, reference to a hen's shameless nature in $179(a, b, c)$, a dog's worthless nature in $181(a, b)$ and a donkey's bad voice in $182(\mathrm{a}, \mathrm{b})$.

Findings of the fourth question revealed that people's ideas and beliefs reflected themselves in their metaphors.It should be added that the types of animals referred to and their connotations in addition to their familiarity and closeness may depend on people's love and appreciation of those animals. Some of the animal expressions had nothing to do with the animals themselves (e.g. the black rabbit, 138). And some were allusions to old stories or folktales (e.g. hoopoe of Solomon the prophet 142). Generally speaking, the salient characteristics of a particular animal, negative or positive attributes ascribed to the animal, reference to overall size or body parts of the animals may differ from one culture to another. This means that each language may have its own peculiarities. As an example, a cowardly person is goat-hearted in Persian, chickenhearted in English and a partridge in Khezeli dialect.The fact that metaphors are culture-specific concepts is acknowledged by scholars such as Deignan, Garbs, and Solska (1997) who maintain that conceptual metaphors and their linguistic rendering are not necessarily the same across languages. Similarly, Deignan (2003: 257) asserts that "if the members of a particular culture hold a particular attitude toward a particular animal, then that animal might be used to stand metaphorically for a particular quality in their language".

Findings for the last research question of the study, represented in the table 2, revealed that out of the 68 animals used in metaphoric expressions, 41 animals were always negative ( 28 wild \& 13 domestic), 11 animals were used both positively and negatively used ( 9 wild \& 2 domestic), and 16 animals were always positive ( 15 wild \& 1 domestic). Since the number of negative animals was greater than that of positive animals and the number of positive animals was greater than dual (positive/negative) attribute animals, it is right to say that negative or degrading animals are more frequently used in the dialect under study. Another finding was that except for ram which was always positive and sheep and ox which were used both positively and negatively, all other domestic animals (13 out of 16 animals) always carried negative connotations.Put in different words, domestic animals almost always connote negative characteristics. 
Why do people use certain animals as positive and others negative or why some of the animals are used both positively and negatively may be explained by Wierzbicka $(1985,1996)$. As she acknowledged, in people's conceptualization of animals the following five basic parameters, namely, habitat, size, appearance, behavior, and relation to people are significant. In the dialect under study, the two parameters of appearance and behavior were found to be the most significant aspects of animal life which reflected themselves in the metaphors due to cultural values. An ugly animal may exhibit desirable behavior (e.g. raven in $21 \& 114$ ) or a beautiful animal may be famous for some unappreciated behavior partridge (79 \& 148). In other words, no matter wild or domestic, big or small, people in the region under study are fond of and appreciate physical beauty and good conduct or behavior of the animals.

It is worth pondering that since beauty and good conduct are relative concepts, so are their definitions and descriptions across cultures and people's views about them. Thus, what might be considered as beautiful or good in one culture or for some people (i.e. males or females) may not be so in another culture. Owl in Persian brings bad luck to the owner but in English it brings the owner wisdom (Talebinejhad/ Dastjerdi2005). The owl's image in Khezeli dialect and Persian is the same.

\section{Implications}

Cultural awareness which has to do with people's language, behavior, beliefs and values is central to intercultural communication and metaphoric awareness is part of this cultural awareness. Metaphor, as Moon (2004) acknowledges, is also common in nonliterary discourse such as academic writing and journalism and failure to understand the messages contained within such metaphors may lead to serious misunderstanding of the text. Moreover, the use of metaphors and metaphoric expressions varies from one culture to another. Accordingly, the interpretation or connotation of one expression may vary widely among different languages and cultures. This cultural aspect of animal metaphors makes metaphors suitable vehicles for transmission and perception of social beliefs. Thus, familiarity with structural patterns as well as knowledge of metaphorical expressions is necessary if one is to avoid misunderstanding in intercultural communication with people from different cultures.

The results of this study have the potential to encourage speakers of every dialect or language variation to be attentive to the metaphoric expressions in their own culture so that they can compare and contrast them with the metaphoric expressions in other cultures. The results may also help them to be more conscious in the use of animal expressions in inter or intra cultural communications, since what is desired in one culture might be offensive in other cultures. The results may also pave the way for future comparative and contrastive analyses of the dialect with other languages or dialects all over the world. The existence of similarities and differences among various languages or dialects and their investigations by the researchers may contribute to the emergence of a new comprehensive and universal theory about metaphor.

\section{Limitations of the Study}

In conducting this study, a number of limitations were tolerated. This study was limited to one dialect of Kurdish language spoken in Ilam while there are some other dialects within this language which are not yet analyzed. Accordingly, the findings of the study cannot be 
generalized to other dialects of Kurdish language due to possible variations that might exist in people's metaphoric expressions. Further, the research was limited to the investigation of one type of metaphors, namely animal metaphors and other types of metaphors were out of focus.

\section{Suggestions for Future Research}

A number of recommendations are put forward for future research and analysis. First of all, since this study was limited to one variety of Kurdish language, it is advisable to investigate other varieties of Kurdish language for future comparative studies. New research may focus on different classes of animals. For example, birds, mammals, amphibious, sea animals, etc. It is also suggested that different languages and dialects of the country be analyzed. More studies may be set up to analyze other languages of various countries which belong to different cultures.

Research may also continue to investigate other kinds of metaphors such as natural elements existing in different dialects or languages all over the world. Besides, due to the possibility of the existence of gender-specific metaphors in some cultures, new studies may be conducted to consider this issue.

Some of the metaphors may be adopted for a particular age range such as children, investigation of which can also be a new subject for further research. Another worthy area of research can concern with the analysis of conceptual metaphors in literary works, poems, novels, short stories, and the like. Still, comparison of the use of animal expressions in different texts or different genres can provide new lines of research. More studies may concern with the frequency of conceptual metaphors in noun, adjective, or verb forms and their positive or negative connotations in different types of discourse which may also reveal interesting findings about the nature of these metaphors.

Mohammad Aliakbari is currently affiliated with the English Department of Ilam University and Elham Faraji is also currently affiliated with the English Department of Ilam University.

\section{References}

Ahrens, Kathleen/Say, Alicia L. T. (1999):"Mapping Image-Schemas and Translating Metaphors". Proceedings of $13^{\text {th }}$ Pacific Asia Conference on Language, Information and Computation. Academia Sinica: 95-102.

Barcelona, Antonio (2000): "Introducion: The Cognitive Theory of Metaphor and Metonomy". In: Barcelona, Antonio (ed.) (2000): Metaphor and Metonymy at the Crossroads. Berlin/New York, Mouton de Gruyter: 1-28.

Brinkmann, Friedrich (1878): Die Metaphern. Studien über den Geist der modernen Sprachen.Vol. 1. Bonn: Adolph Marcus.

Deignan, Alice (2003): "Metaphorical Expressions and Culture: An Indirect Link". Metaphor and Symbol 18/4: 255-271.

Deignan, Alice/Gabrys, Danuta/Solska, Agnieszka (1997): "Teaching English Metaphors Using Cross-Linguistic Awareness-Raising Activities". ELT Journal 51/4: 43-51.

Fernández Fontecha, Almudena/Jiménez Catalán, Rosa Maria (2003): "Semantic Derogation in Animal Metaphor: A Contrastive-cognitive Analysis of Two Male-Female Examples in English and Spanish". Journal of Pragmatics 35: 771-797.

Fraser, Bruce (1981): "Insulting Problems in a Second Language". TESOL Quarterly 15/4: 435441. 
Harris, Marvin (1985): Good to Eat: Riddles of Food and Culture. New York: Touchstone/ Simon \& Schuster.

Howard, Alan/Rensel, Jan (1991): "Animal as metaphors in Rotuman Sayings". In: Pawley, Andrew (ed.) (1991): Man and a Half: Essays in Pacific Anthropology and Ethnobiology in Honour of Ralph Bulmer. Auckland: Polynesian Society.

Hsieh, Shelley Ching-Yu (2001): Tiermetaphern im Modernen Chinesischen und Deutschen. Eine Vergleichende Semantische und Soziolinguistische Studie. Unpublished doctorial dissertation, University of Tübingen.

Hsieh, Shelley Ching-Yu (2004): "The Corpora of Mandarin Chinese and German Animal Fixed Expressions: A Cognitive Semantic Application". University Centre for Computer Corpus Research on Language Technical Papers, Special Issue, 18, 27-35 England: The University of Birmingham.

Kiełtyka, Robert/Kleparski, Grzegorz Andrzej (2007): "On the Indo-European Nature of NonIndo-European Animal Metaphor: The Case of Chinese Zoosemy". Studia Anglica Resoviensia 4/47: 88-99.

Kleparski, Grzegorz Andrzej (2002): "Lusta, Mint a Disznó: A Hunt for 'Corrective' Zoosemy in Hungarian and English". Studia Anglica Resoviensia 1: 9-32.

Kövecses, Zoltan (2002): Metaphor: A Practical Introduction. Oxford: Oxford University Press.

Kövecses, Zoltan (2003): "Language, Figurative Thought and Cross-Cultural Comparison". Metaphor and Symbol 18/4: 311-320.

Kövecses, Zoltan (2006): Language, Mind, and Culture: A Practical Introduction. New York: Oxford University Press.

Lakoff, George/Johnson, Mark (1980):Metaphors We Live By. Chicago: University of Chicago Press.

Lakoff, George/Turner, Mark (1989): More Than Cool Reason: A Field Guide to Poetic Metaphor. Chicago/London: University of Chicago Press.

Leung, Winifred Yuk Ying (2008): "A Contrastive Study of Chinese and English Metaphors of Marriage". LCOM papers 1/08: 21-35.

Li, Guonan (2001): Figure of Speech and Glossary. Shanghai: Shanghai Foreign Language Education Press.

Liu, Dilin (2002): Metaphor, Culture, and Worldview: The Case of American English and the Chinese Language. Lanham: University Press of America.

López Rodríguez, Irene(2009):"Of Women, Bitches, Chickens and Vixens: Animal Metaphors for Women in English and Spanish".Culture, Language and Representation 7: 77-100.

Martsa, Sandor (2000): "On Animal Frames in English and Hungarian". In: Mogensen, Jens/Pedersen, Viggo/Zettersten, Arne (eds.) (2000): Proceedings of the Ninth International Symposium on Lexicography at the University of Copenhagen. Tübingen, Niemeyer:113124.

Moon, Rosamund (2004): "On Specifying Metaphor: An Idea and its Implementation". International Journal of Lexicography 17: 195-222.

Nesi, Hilary (1995): "A Modern Bestiary: A Contrastive Study of the Figurative Meanings of Animal Terms". ELT Journal 49/3: 272-278. 
O'Donnell, Paul (1990): "Entre Chien et Loup: A Study of French Animal Metaphors". The French Review 63: 514-523.

Olateju, Adesola (2005): "The Yorùbá Animal Metaphors: Analysis and Interpretation". Nordic Journal of African Studies 14/3: 368-383.

Sanaie, Yaser (2008): Poems of Wali Mohammad Omidi. Ilam: Raman Publication.

Riegler, Richard (1907): Das Tier im Spiegel der Sprache: Ein Beitrag zur Vergleichenden Bedeutungslehre. Dresden/Leipzig: C.A. Kochs Verlagsbuchhandlung.

Shih, Pei-chin (2006): Chinese Zodiac: A Case of Chain Metaphors. Master Thesis, University of Providence.

Song, Meiying(2009):"Cognitive Analysis of Chinese-English Metaphors of Animal and Human Body Part Words". International Education Studies 2/3: 57-59.

Taggart, James M. (1982): "Animal Metaphors in Spanish and Mexican Oral Tradition". The Journal of American Folklore 95/377: 280-303.

Talebinejhad, M. Reza/Dastjerdi, H. Vahid (2005): "A Cross-Cultural Study of Animal Metaphors: When Owls Are Not Wise". Metaphors and Symbol 20/2: 133-150.

Taverniers, Miriam (2004):"Grammatical Metaphors in English". Modern Sprak 98/1: 17-26.

Thornton, Freda J. (1989): A Classification of Semantic Field 'Good and Evil' in the Vocabulary English. Doctoral dissertation, University of Glasgow.

Wierzbicka, Anna (1985): Lexicography and Conceptual Analysis. Oxford: Oxford University Press.

Wierzbicka, Anna (1996): Semantics: Primes and Universals. Oxford: Oxford University Press.

Ying, Sheng (2007). "The Role of Culture in Metaphor". US-China-Foreign Language 5/1: $74-80$.

\section{Appendix}

\section{List of metaphoric expressions in English and their original quotes.}

\subsection{Appearance metaphors}

\subsubsection{Body part metaphors}

\subsubsection{Hair metaphors}

1. Her hair is a snake's tail, ميودم ماره (long plaited hair is appreciated and likened to the snake's tail).

2. Her hair is a scorpion's tail, ميو دم ثه قروه (the curved tail of the scorpion is appreciated and curved hair is likened to it).

3. Black-raven hair, ميو سه رجيوقلاسئ (the black feather is likened to the black hair of a person).

4 (a). Her/his hair is a goat's tail, ميو دم بزن (for unpleasant coarse hair).

4 (b). Her/his hair is a bald goat's hair, بزن كه 2 (to degrade a person who has lost his/ her hair).

4 (c). Her/his hair is the wolf-torn hair of a goat, كوركانه خوه رد (for disgracing a person who lost most of his/ her hair). 
5. Her/ his hair is a mule's tail, ميو مه نخه دم قاتر (refers to coarse hair).

\subsubsection{Eye metaphors}

6. Hawk-eyes, جيه م مه نخه جيه م باز (people appreciate the keen eyesight of the animal).

7. Gazelle-eyes, דيه م مه نكه جيه م قه زال (this animal is famous for having very beautiful eyes).

8. Deer-eye, רيه م مه نكة جيه م ثاهوو (this animal is famous for having very beautiful eyes).

9. Ox-eye, جيه من (big eyes of this animal are praised by people).

10. Mole-eye, ميووش كورو (refers to eyes which are small for the body).

11. Cat-eyed, بشى حيه م (refers to small blue eyes).

12. Salamander-eye, خيم مه نحه جيم قوز (salamander is a small poisonous red or white spotted reptile with eyes that are big for its body).

13 Frog-eye, قرواق حيه م (refers to very big eyes).

14. Owl-eye, بيوخيه م (refers to big and round eyes).

15. Donkey-eye, خه رجيه م (refers to ugly big eyes).

16. Chick-eye, جيووجگ جيه م (refers to very small eyes).

17. Whelp-eye, تيووتخ حيه م (whelp is a very young dog and this expression refers to very small eyes).

\subsubsection{Nose metaphors}

18. Ram-muzzle, وه رهن نيووز (refers to a beautiful nose).

19. Monkey-nose, ميموون ليووت (monkey is disgraced for its big, broad, and ugly nose).

20. Eagle-nose, يوقاب ليووت (refers to a long and curved nose).

21. Raven-nose, قلا ليووت (refers to a long and curved nose).

22. Cow-nose or ox-nose, هنغ ليووت (refers to a broad, big and ugly nose).

23. Mule-nose, قاتر ليووت (refers to a broad, big and ugly nose).

\subsubsection{Lip metaphors}

24. Pearl-oyster lip, يو س ه ده في (refers to thin lips).

25. Camel-lip, شترلوس (refers to very big lips).

26. Cow/ ox lip, كالقس (refers to very big lips). 


\subsubsection{Tooth metaphors}

27. Her/his tooth is an elephant's tooth, دنان مه نكه دنان فيل (an elephant's ivory is considered white and very hard and connotes strong teeth).

28. Warthog's tusk-tooth, وراز دنان (refers to very long and protruding teeth).

29. Mouse-tooth, ميووش دنان (refers to very small teeth).

30 Donkey-tooth, خهن (refers to very big teeth).

\subsubsection{Chin and mouth metaphors}

31. Warthog-chin, وراز ده م (refers to a badly shaped chin like a warthog's snout).

32. Monkey-chin, ميموون ده م (refers to a very unpleasant chin).

33. Frog-mouth, قرواق دهم (refers to a wide mouth).

34. Wolf-mouth, گورگ ده م (refers to a wide and ugly mouth).

35. Mule-chin, قاتر ده م (refers to a very big chin).

36. Whelp-chin, تيووتخ دهم (a very small and ugly chin is likened to a whelp's muzzle).

\subsubsection{Ear and hearing metaphors}

37. Her/his ear is a snake's ear, كوش مار ديّريّ (refers to quick sense of hearing).

38. Her/his ear is a deer's ear, كووشئ جيوو ثاهوو تيزّه (this animal is well known for its beauty of ears and quick sense of hearing).

39. Her/his ear is a mouse's ear, كووشيَ مه نكَ كووش ميووش (refers to sharp sense of hearing).

40. Mule-ear, قاتر ليووت (refers to very large ears).

\subsubsection{Neck metaphors}

41. Deer-neck, شكار مل (refers to a long, beautiful neck).

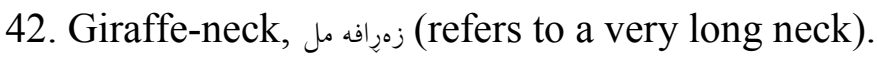

43. Frog-neck, قروقوق مل (refers to an unpleasantly short neck).

44. Goose-neck, قاز مل (refers to a very long neck).

45. Vulture-neck, دال مل (refers to an unpleasantly long neck).

46. Warthog-neck, وراز مل (refers to a short, big neck).

47. Monkey-neck, ميموون مل (refers to a person with a small head and a very thin neck).

48. Camel-neck, شتر مل (refers to a very long and ugly neck). 
49. Turkey-neck, بووق مل (refers to a very long neck).

50. Donkey-neck, خه (refers to a big and thick neck).

\subsubsection{Head metaphors}

51. Lion-head, كه له جوور كه له شئره (refers to a nice big head).

52. Elephant-head, سه ر كه يوول مه نحة سه ركه يوول فيل (refers to a nice big head).

53. Partridge-head, كو سه , (refers to a very small head).

54. Owl-head, بيوو سه ر (refers to a big head).

55. Lark-head, كول كولّاوه سه ر (with a crest on its head, lark is known for its small unpleasant head).

56. Chameleon-head, قوم قو مه ك سه (this type of lizard lives in mountainous areas and has an unpleasant small head. Its metaphor connotes an ugly small head).

57. Sparrow-head, مه ليووجگ سه J (refers to a very small head).

58. Donkey-head, خه ر سه (refers to a big head).

59. Dog-head, كه مالَ سه (refers to a big head).

60. Hen-head, وإئ سه ر (it refers to a small and slim head).

61. Chick-head, جيووجگ سه (it refers to a very small and slim head).

\subsubsection{Hand metaphors}

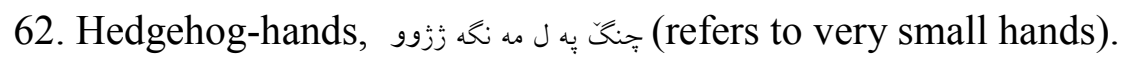

63. Monkey-hands, ميموون ده س (refers to long, dark skin, unpleasant hands).

64. Crab-hands, ده س قر جنّى (refers to rough, coarse hands).

65. Bear-hands, ده جو جوور خرسه (refers to unpleasantly big hands).

66. Leopard-hands, ده س و به نجيَ جوور به لَّ نحّة (refers to very big and destructive hands).

\subsubsection{Leg metaphors}

67. Her/his shin is an elephant's shin, مج يا مه نحه مج يائ فيل (refers to nice fat feet).

68. Her shin is a deer's shin, ساق يانّ ثاهوو (refers to a nice long shin).

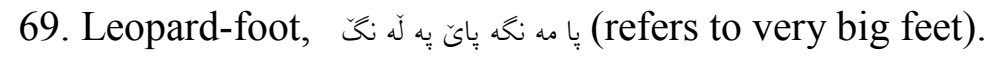

70. Bear-foot, بٌ مه نكَه بإئ خرس (refers to very big feet). 
71. Hedgehog-foot, با مه نحَه بائ زُزوو (refers to a very unpleasantly short and small leg).

72. Mule-foot, با مه نحه بِايَ قاتر ( refers to very big feet).

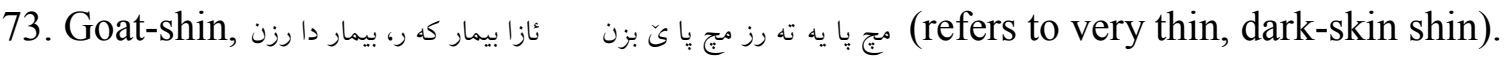

\subsubsection{Whole body metaphors}

\subsubsection{Figure metaphors}

74. What a blond eagle, دال هيوول (refers to very handsome, blond person).

75. Look at this deer, بره ثاهووه (refers to a lovely figure).

76. Look at this fish, مه نحة ماهى (refers to a well-shaped woman, people appreciate the physical beauty of fish which is neither fat nor thin).

77. Long giraffe, زرافه (refers to a very unpleasantly tall person).

78. She/he is a slim hound, مه نكه تانجى (refers to a very ugly and thin person).

\subsubsection{Metaphors for beauty}

79. She is a partridge, oه نح كت (this animal is famous for its graceful beauty).

80. She is a beautiful gazelle, مه نكه قه زال (refers to the beauty of the body and eyes of a woman).

81. She is a white swan, به تيخه (it refers to a woman's white skin).

82. Oh, the pea-hen lady, هئ، تاووس خانم (refers to the utmost beauty of a woman).

\subsubsection{Metaphors for ugliness}

83. Fox burnt in the jungle, عووى يه قورق سزيا (refers to a very unattractively dark and slim person).

84. She/he is a hedgehog, مه نكه زُزوو (refers to a very short and unattractive person).

85. You slim jackal, جه قه ل كّ له (refers to an unattractive, slim person).

86. You monkey, ميموون (refers to an ugly person).

87. You frog, قروقاق (refers to one's ugliness).

88. You crocodile, دالكَه ماران (the Zagrosi type of crocodile living in the area is long and thin; its body is like snake but it has small legs. It refers to an unattractively slim person).

\subsubsection{Metaphors for thinness}

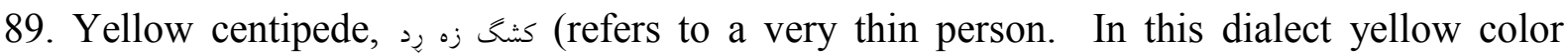
symbolizes one's thinness and weakness).

90. Yellow snake, 2 مار (refers to a very thin and pale person). 
91. You chick, جيووجگ (it refers to a person who is very small and thin).

\subsubsection{Metaphors for fatness}

92. Look at this warthog, بره ورازه (refers to a very fat person).

93. The big bear, خرس قيق (refers to an unpleasantly fat person).

94. He/she is a rat above treasure, كريزه ني بانئ خه ز ينه (refers to a fat person or a person who has gathered wealth without trouble).

95. She/he is a big cow/ox, كائ سه ين (refers to a fat person).

\subsection{Behavioral metaphors}

\subsubsection{Metaphorization of wild animals used for praising}

A quick person is one who has the most salient feature of quickness found in hound, rabbit, tarantula, gazelle, hawk, and dull-yellow-partridge.

96. She/he is a hound, مه نكة تانجى (hound is famous for being very fast since it runs quickly).

97. She/he is a (quick) rabbit, مه نحه كه رويّ (a rabbit runs quickly).

98. You tarantula, حتئله (this animal is also very quick and runs fast).

99. She is a quick gazelle, مه نكه قه زال (gazelle runs very fast when endangered. This metaphor is often used to refer to a very quick and clever woman).

100. He is a hunter-hawk, مه نحة باز شكارى (hawk flies very fast while hunting).

101. Dull yellow partridge, مه نكة سووسگ (this bird is also famous for being very quick when it flies).

A light sleeper is mostly linked to a partridge.

102. Her/his sleep is a partridge's nap, كوكه م خاو (this animal wakes up with a very slight or soft noise or sound).

A very intelligent person is associated with the wild animal deer.

103. She/he is a deer ahead of stampede, شكاريّ نوائ جه م (it refers to the characteristic of the animal which cares for every small sound, smells every smell and reacts quickly for the fear that they may come from her enemies).

A good tempered person is linked to a turtledove.

104. A good-tempered turtledove قو مرى خوه ش اخلاق (people consider this bird as a kind bird because it does not hurt any other creatures).

A good voiced person has characteristics found in partridge and nightingale.

105. Her voice is a partridge's singing, شاقه يَه ما يَّق (partridge sings sweetly, especially in spring). 
106. He/she is a good-voiced nightingale, حيوو بول بول مه خوهنيك (people enjoy hearing the singing of nightingales).

A person with soft words is a parrot.

107. A soft word parrot, تووتى شيرين زوانيكَ (it refers to the special capability of this animal that can be trained to copy human speech like a young child whose speech is a lovely repetition of his parents').

A content person has a snake-like characteristic.

108. The not eating anything snake, ئرا مارم وهخه حقى قاني بووم (it is said that this animal does not eat anything in winter).

A powerful or strong person is associated with the wild animals, leopard, tiger, and elephant.

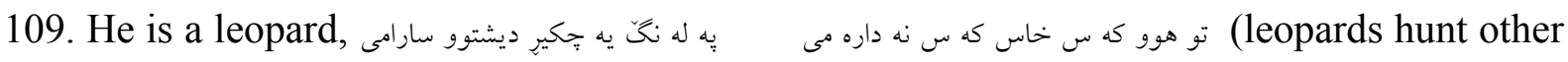
animals and are very strong in fighting).

110. He is a tiger, مه نكة به بر (just like leopards, tigers are also strong when they fight).

111. He is an elephant, جهه نه فيل زوور دئ (elephant is also famous for being strong, mostly because of its very large body).

A brave person is described as a lion.

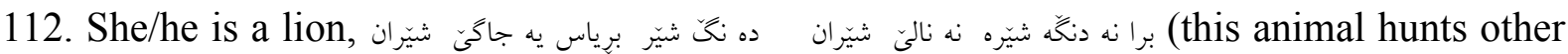
animals and is said not to fear any other animal).

A humble, shy or polite person is linked to a leopard or raven.

113. She/he is a shy leopard, شه رميَ به له نحّ ديّرى (contrary to other animals, leopards do not couple when others are present).

114. She/he is a shy raven, شه رم قلّا ديرِيّ (like leopards, ravens do not couple publically).

A person with long-term memory is like a raven.

115. I don't have the raven's memory, هيوور قلّا نيّرم (ravens have very excellent memories; they easily remember the places where they hid the things they had stolen long ago).

\subsubsection{Metaphorization of domestic animals used for praising}

An honest person is likened to a sheep (it refers to the calmness of sheep).

116. She/he is a prophet's sheep, ميَ بيّخه م به ريَّك (it refers to thebehavior of the animal which is very calm. The use of such a collocation "prophet sheep" transfers the idea of sheep's honesty. Moreover while grazing, unlike goats, sheep do not eat their shepherd's food).

\subsubsection{Metaphorization of wild animals used for degrading}

A weak person is mostly associated with owl. 
117. Look at this owl, بيوويَكه (it refers to the behavior of the animal that most often is silent and does not move. It merely hunts small animals mostly at night and it does not fight other animals).

A heavy sleeper islikened to a bear.

118. The sleepy-head bear, خرس خاوالو (it refers to the behavior of the animal that sleeps during winter).

A taciturn person is an owl.

119. The taciturn owl, بيوو مه كوويكَه (it refers to the behavior of the animal that is most often silent and rarely makes any sound).

A big eater person is like the wild animal snake in that its belly is never protruded.

120. Snake-belly, مار زگ (it refers to a person who eats a lot but his/her belly is not fat).

A small eater person eats like a sparrow.

121. She/he sparrow-eats the food, مه ليوو جع خوه غن ذا مه كي (it refers to the behavior of the animal that eats a little).

A bad tempered person is likened to a hedgehog, snake or wolf.

122. Youhedgehog, زjو (it refers to defense-like state of the animal when threatened).

123 (a). Her/his tongue is a snake's tail, مه نكة دم مار (the bitterness of the tail of the animal is likened to one's bad-temperedness).

123 (b). Her/his tongue is snake's venom, مه نحه زه هر مار (the bitterness of the venom of the animal is likened to the bitterness of a bad-tempered person).

124. She/he is a rabid wolf, كورگ هاريكَ (it refers to the behavior of the animal that attacks other animals wildly and is likened to a person who is ready to attack other people).

A shrewd and astute person is likened to a number of wild animals including lizard, mouse, and centipede.

125. She/he is a lizard, هيَ مارميوولك (it refers to the behavior of the animal which scuttles into every hole).

126. She/he is a dead mouse, ميوشيَ مرديى (when in danger, this animal does not move as if it is dead. A shrewd person who is silent or hides himself when he has committed an evil act is likened to this animal).

127. She is a centipede under the stone, كشخ زيّر كو جخع (it refers to the animal that despite having lots of legs moving under stones is not seen; an astute person's intention is not seen).

A grumbling person is a fox or a bear crying from pain.

128. The groaning-fox, يووى زان كيدي (it refers to the behavior of the animal that groans from stomachache). 
129. The loud-voice bear, خرس بوولّن (when injured or upset bears roar unusually loud).

A cunning person is the wild animal fox, jackal, or an old wolf.

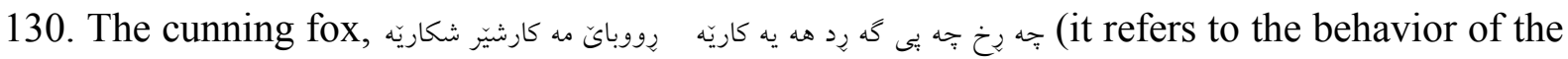
animal that hunts with trickery since it hides itself and waits until its victim arrives. It does not have the power to fight big animals and eats only small animals).

131. The cunning jackal, جָه قם J (just like 130).

132. The old wolf, كورگ بي (just like 130).

A cruel person behaves as if she/he is a wolf, cat or an ant.

133. What a wolf, كوركان به عسى مه كيشان زوزه خزل سووره ت يه كيّان بووسه (it refers to the behavior of the animal that kills the whole cattle when hunting).

134. You cat-natured, بشى صفت (it refers to the behavior of the animal thateats her own kitten in extreme hunger).

135. The snake-eater ant, مريووز مار خوه ر (contrary to its small size, an ant can carry very big loads; this expression refers to a person who looks innocent but commits evil actions).

An unlucky person is linked to a number of wild animals including raven, owl, and rabbit. They are known as messengers of unhappiness since ancient times.

136. She/he is an unlucky raven, ü (this refers to the behavior of the animal for announcing cool weather or snow which are bad news for farmers; this animal brings bad news).

137. She/he is an unlucky owl, جوقد شووم (this refers to the behavior of the animal which lives in ruined and quiet places. In people's view, the animal and the places it lives in are symbols of misfortune).

138. The black rabbit, سيّ كه روين (from ancient times people believed that seeing a rabbit during a journey brings misfortune. The black color refers to a bad omen).

A bad voiced person is like the wild animal bear.

139. Keep your bear-voice down, خرس بوولن، بووله د باره خوار (people believe that bear makes unpleasant sounds).

A rush person isequated with monkey.

140. You, monkey, ميموون (it refers to the behavior of the animal that jumps quickly and hastily from one tree to another).

A meddlesome person is linked to a raven, hoopoe or an ant.

141. She/he is a meddler raven, ü (because of bringing the bad news of cool weather, she is famous for being a meddler). 
142. Stop meddling! The hoopoe, بازه ك حه زره ت عن سليّمان كه مزوولى بكه (it alludes to the hoopoe of Solomon the Prophet to whom she brought news).

143. You ant, مريوزخ (since an ant is very small, it goes everywhere even into very small holes. It refers to a person who interferes in other people's affairs).

An obstinate person is likened to a warthog.

144. The fixed-neck warthog, وراز ين كرى مل (it refers to the characteristic of the animal that can only move in a direct line and cannot move its head; an obstinate person also moves in his/her own way).

A shameless person acts like a wolf, sparrow, and she-wolf.

145. The shameless wolf, كور كَيكَ (it refers to the behavior of the animal that unlike other animals does not fear from any sound and keeps moving ahead).

146. The impudent sparrow, مه ليووجى بيوودار (this bird does not care whether others are present when it couples).

147. She is a she-wolf, ده له كوركيَّه (people attribute the characteristic of this animal to a person who shamelessly and cruelly does everything to achieve her goals.)

A coward person's behavior is likened to a timid partridge.

148(a). You are partridge's gall bladder, ز ز لَ (it refers to the behavior of the animal that runs away when it feels that someone or something is getting closer; it may also die from fear).

148(b).There is no partridge flapping in his/her heart, يرت كق يه دلي نيه (partridge is also famous for its cowardice and this metaphorical expression refers to a person who is easily frightened, even by flaps of partridge's wings; a coward who is frightened by a coward).

A greedy person is associated with amouse or a wolf.

149. A loss-making mouse, ميووش زيان كه ر (when it attacks a stock of grain, it eats from all parts of the stock and makes it dirty).

150. What a greedy wolf, كورى حه ريص (it refers to the behavior of the animal that kills the whole cattle when hunting though it cannot eat all of them).

A covetous person is one who acts like a vulture.

151. Look at this vulture near the dead corpse, دال ديار له 25 (it refers to the behavior of the animal that eats the remainder of other animals' victims).

A dirty person is the one who is mostly like a pig or a warthog's cub.

152. Oh, dirty pig, خووى يّيس (in the Islamic tradition pigs are considered unclean).

153. Warthog's cub, وه: تحكه للكه (people also believe that warthog's cubs are dirty because they lay in mud or their own excrements).

A talkative person is one who cries like a hyena. 
154. Stop crying! The crying hyena, كه م بقلنّن (it refers to the behavior of the animal thatmakes sounds most of the time without any reason. This metaphor refers to a person who talks a lot meaninglessly).

A person who stays awake at night is also likened to an owl.

155. Sleep, owl, بايّه قوز بخه ف (this refers to the behavior of the animal that is awake all the night).

A person with a sharp tongue is related to a scorpion or a snake.

156. Her/his tongue is a scorpion's sting, زواني نيشي ئه قروه (a scorpion's sting is fatal. A person with a sharp tongue also annoys and kills others spiritually by his or her words).

157. Her/his tongue is a snake's fang, زواني نيشي ماره (a snake's fang is also fatal and a person who annoys others with his/her words kills them spiritually).

\subsubsection{Metaphorization of domestic animals used for degrading}

A slow person is likened to a cow, a broody hen, or a lame donkey.

158. The slow cow/ox, كاته مه ل (it refers to the behavior of the animal which moves slowly).

159. The broody hen, مرخ كح (it refers to the behavior of the animal which sits on the eggs for a long time without movement).

160. The lame donkey, خه رشه (refers to the behavior of the animal that is not able to walk correctly because of physical injury to or weakness in its legs or feet).

A restless and anxious person is likened to a hen in the following metaphor.

161. She/he is a flapping hen, مرخ سه ربيا (it refers to the behavior of the animal that shakes its wings repeatedly when its head is cut).

A cruel person is most often associated witha dog.

162 (a). You rabid dog, سه كَ هار (a rabid dog bites and attacks everyone).

162(b). You dog-natured, سه ك صفت (dog is said to fight, attack, bite, or kill other creatures whenever it feels it can do it and its calmness is not permanent).

A stupid person is linked to certain domestic animals such as a donkey, sheep, a cow, a packhorse, or a turkey.

163. The stupid donkey, , (it refers to the behavior of the animal which stays and brays when a wild animal attacks and does not run away).

164. Confused sheep, טه س وي (it refers to the behavior of the diseased sheep which is always confused. Confusion is a kind of animal disease).

165. Confused cow/ox, كائ وي (it refers to the behavior of the animal which is confused of sickness). 
166. She/ he is a pack-horse or you pack-horse, يابوو (pack horse is considered stupid in the dialect under study).

167.Turkey-mind, بووق مه غز (turkey is also considered stupid in Khezeli dialect).

A weak person is likened to a kid or a chick.

168. Dead-mother kid, كيه ر دالكَ مردي (a kid whose mother has died has no one to protect or feed it).

169. Last hatched Chick, جيوو جیى دمالان (nothing remains for the last hatched chick because the earlier hatched chicks have eaten everything; it often dies from weakness).

A low spirit person is assimilated into a hen.

170. Blue-crest-stricken hen, مامر يوويكه كت كرئi (blue crest is a kind of disease because of which the crest becomes blue. A blue-crest suffering hen loses her freshness and health and tends to detach herself from the rest of the group).

A thoughtless person acts like a cow.

171. You, the thoughtless cow/ ox, كا، بره سئو (it refers to the behavior of the animal which moves slowly in time of danger).

A revengeful person is likened to a camel.

172. She/he is a revengeful camel, كينه شترى (it refers to the behavior of the animal that is thought to remember even a bit annoyance done to it and revenges the person who has done so).

A bad tempered personor a naughty child isassimilated intoa dog, a mule, or a horse.

173. A bad tempered dog, سه ك به د اخلّاق (it refers to the behavior of the animal which barks at everyone except its owner no matter young or old).

174. She/he is a vicious mule, قاتر جه ميووش (a vicious mule always kicks, it refers to a naughty child).

175. She/he is a vicious horse, ثه سب جه ميووش (a vicious horse always kicks, it refers to a naughty child).

A big eater person is likened to a cow / ox.

176. The big-eater cow/ox, كائ فره خوه ر (this animal eats a lot).

A small eater person is associated with a chick.

177. The small eater chick, جيوجيخ هيووج مه خو مر (it refers to the behavior of the animal which eats a little).

A shameless person is linked to a dog or hen.

178. The shameless dog, سه كَ ي يوودار (refer to 173). 
179 (a). A pitgaurd-hen, مرخ خا له وان (in ancient times people used to store their grains in large holes in the ground and a guard used to keep the animals and thieves away from the pits. Yet, hens did not care about the guard's shoo and continued taking grains from pits).

179(b). She is a shameless hen, مرخ ريوودار (refers to the behavior of the animal which does not care about human shooing).

179 (c). You are inattentive to shoo, كش مه زان (refers to the behavior of hens that do not care about human shooing).

A worthless person is most often associated with an old mule or a dog.

180. You old mule, قاتر ييي (it refers to the old animal that cannot carry any load because of old age and is thus worthless).

181(a). Not barking dog بֶّ مه كه , (a dog is only useful when it barks on time. Whenever a dog does not bark in due time, it is worthless).

181(b). You untimely dog, كه م ياس بكه (an untimely dog barkswheneverit likesand its barking does not mean that something has happened).

A bad voiced person has a sound like a donkey.

182 (a). Keep your donkey voice down, ده نح نيره خه ريده باره خوار (people believe that donkey has an unpleasant sound).

182 (b). Stop braying, كه م بسه رن (as the above).

A proud and arrogant person behaves like a cock or dog.

183. The arrogant cock, كلّ شيَر قوت (it refers to the behavior of the animal that holds its head and neck in an upright manner and walks proudly).

184. Arrogant young (dog) ahead of a migration, جاهل نوائ هئول (the arrogant young is likened to a dog which should walk at the end of the cattle but because of his arrogance walks ahead of all).

An obstinate person is a donkey.

185. The obstinate donkey, هو (it refers to the behavior of the animal which tries to move ahead if another donkey is also going to carry its load in the same direction).

An unpunctual person is a cock.

186. You unpunctual cock, كله شيّرنه وه وه خت (it refers to the behavior of the animal that crows untimely).

A dirty person is most associated with a dog or a goat.

187. You dirty dog, سه ك يُّ (it refers to the Islamic tradition in which dogs are considered unclean). 
188. You bald goat, بزن كه 2 (it refers to the unpleasant appearance of a goat who has lost its fleece for sickness. People in this region consider a diseased animal as dirty).

A talkative person is linked to a dog.

189.She/he always barks, ثقه پِاس مه كه (it refers to a dog that barks most of the time without any reason or meaning, it refers to a person who talks nonsense). 